\title{
Annual Report on External Quality Assessment of Viral Markers and Serological Tests for Syphilis in Korea (2013)
}

Jun Hyung Lee ${ }^{1}$, Young Joo Cha ${ }^{1}$, Jae Hoon $\mathrm{Bae}^{1}$, and Seok Lae Chae ${ }^{2}$, as Immunoserology Subcommittee, The Korean Association of Quality Assurance for Clinical Laboratory ${ }^{1}$ Department of Laboratory Medicine, Chung-Ang University Hospital, ChungAng University College of Medicine, Seoul; ${ }^{2}$ Department of Laboratory Medicine, Dongguk University Ilsan Hospital, Dongkuk University College of Medicine, Goyang, Korea
We performed two trials on the external quality assessment of viral markers and serological tests for syphilis (STS) organised by the Immunoserology Subcommittee of the Korean Association of Quality Assurance for Clinical Laboratories in 2013. In each trial, we delivered 3 kinds of pooled sera specimens to 1,021 institutions for external proficiency testing. Pooled sera were checked for their homogeneity and stability by using more than 3 other methods between the day of their manufacture and 3 days after despatching. The numbers of participating laboratories were 1,019 (99.8\%) and 1,020 (99.8\%) for the first and second trials, respectively. The most commonly tested items were hepatitis B surface antigen followed by antibody to hepatitis B surface antigen, anti-human immunodeficiency virus, anti-hepatitis $\mathrm{C}$ virus, STS, and anti-hepatitis B core. The most frequently used methods for detecting viral markers were the chemiluminescence immunoassay (CLIA) and the electrochemiluminescence immunoassay, which generated a few false positive results. In contrast, false negative results were frequently found through the immunochromatography assay, the use of which for detecting viral markers has been steadily increasing in recent years. The new tests, turbidoimmunoassay and CLIA, have recently been introduced for the measurement of non-treponemal and treponemal antibodies, and their use is also increasing. (J Lab Med Qual Assur 2014;36:161-170)

Key Words: Hepatitis B, Hepatitis C, HIV, Immunoassay, Laboratory proficiency testing, Serology, Syphilis

\author{
Corresponding author: \\ Young Joo Cha \\ Department of Laboratory \\ Medicine, Chung-Ang University \\ College of Medicine, 84 \\ Heukseok-ro, Dongjak-gu, Seoul \\ 156-861, Korea \\ Tel: $+82-2-6299-2720$ \\ Fax: +82-2-6298-8630 \\ E-mail: chayoung@cau.ac.kr
}

pISSN: 1225-097X

elSSN: 2288-7261

\section{서론}

대한임상검사정도관리협회 면역혈청분과위원회는 1982년 B형간염표면항원(hepatitis B surface antigen, $\mathrm{HBsAg}$ )과 매독혈청검사(serologic test for syphilis, STS)에 대한 신빙
도조사를 시작으로, 1983년부터 항-스트렙토라이신 O (antistreptolysin O, ASO)와 위달(Widal), 1986년부터 C-반응단 백(C-reactive protein, CRP)과 류마토이드인자(rheumatoid factor, $\mathrm{RF}$ ), B형간염표면항체(antibody to hepatitis B surface antigen, anti-HBs), 1992년부터 에이즈항체(anti- 
human immunodeficiency virus, anti-HIV), 1993년부터 C 형간염항체(anti-hepatitis C virus, anti-HCV), 2004년부 터 B형간염중심항체(antibody to hepatitis core antigen, anti$\mathrm{HBc}$ )에 대한 신빙도조사를 실시해오고 있다[1-5]. 2013년에는 HBsAg, anti-HBs, anti-HBc, anti-HCV, anti-HIV, STS, $\mathrm{ASO}$, Widal, $\mathrm{CRP}, \mathrm{RF}$ 등 총 10종목에 대하여 연 2회 신빙도 조사를 실시하였다. 저자들은 이 중 HBsAg, anti-HBs, anti$\mathrm{HBc}$, anti-HCV, anti-HIV, 및 STS검사의 신빙도조사결과를 분석하여 보고하고자 한다.

\section{재료 및 방법}

\section{1. 정도관리 검체 및 대상기관}

총 2회에 걸쳐 바이러스 항원/항체 및 STS에 대한 신빙도 조사를 실시하였다. 1회차 신빙도조사 정도관리 검체는 2013 년 5월 6일 발송하였다. 검체는 바이러스 항원/항체검사용 2 개(13-S-3, 13-S-4)와 STS용 1개(13-S-5)로 총 3개의 검체를 1,021 개 기관에 발송하였다. 2 회차 정도관리 검체도 1 차와 마 찬가지로 총 3개의 검체( $13-\mathrm{S}-8,13-\mathrm{S}-9,13-\mathrm{S}-10)$ 를 1,021 개 기관을 대상으로 2013년 11월 12일에 발송하였다.

\section{2. 신빙도조사 대상종목}

신빙도조사 대상종목은 $\mathrm{HBsAg}$, anti-HBs, anti-HBc, anti-HCV, anti-HIV, 및 STS로 총 6종목이었고, 1회와 2회 차 모두 동일한 종목을 대상으로 하였다.

\section{3. 정도관리 검체 제조방법}

신빙도조사를 위한 정도관리 검체는 '인체유래 고위험군 바이러스 소재은행'인 ‘중앙대학교병원 혈청검체은행'으로 부터 혈청을 분양받아 각 종목의 양성과 음성 정도관리 검체 를 제조하였다. 냉동보관된 혈청을 실온에서 해동한 후 $56^{\circ} \mathrm{C}$ 에서 3 시간 불활성화시키고 $0.22 \mu \mathrm{m}$ 필터에서 1 회 여과시켰 다. 적절한 역가가 되도록 양성 및 음성 혈청을 혼합하고 7일 간 냉장고에 보관하면서 1시간 간격으로 교반기에서 $150 \mathrm{rpm}$ 으로 혼합하여 균질한 검체를 제조하였다. 이후 검체 균질성 (homogeneity) 및 안정성(stability) 검사를 실시하였고, 검체 를 담을 작은 병(vial)과 고무마개를 ethylene oxide 가스로 멸 균하고, 무균실험대(clean bench)에서 작은 병에 $1 \mathrm{~mL}$ 씩 분 주한 후 고무마개를 밀봉(packing)하였다. 용기의 파손을 대 비하여 추가로 스크류캡(skew cap)에 밀봉하여 발송하였다.

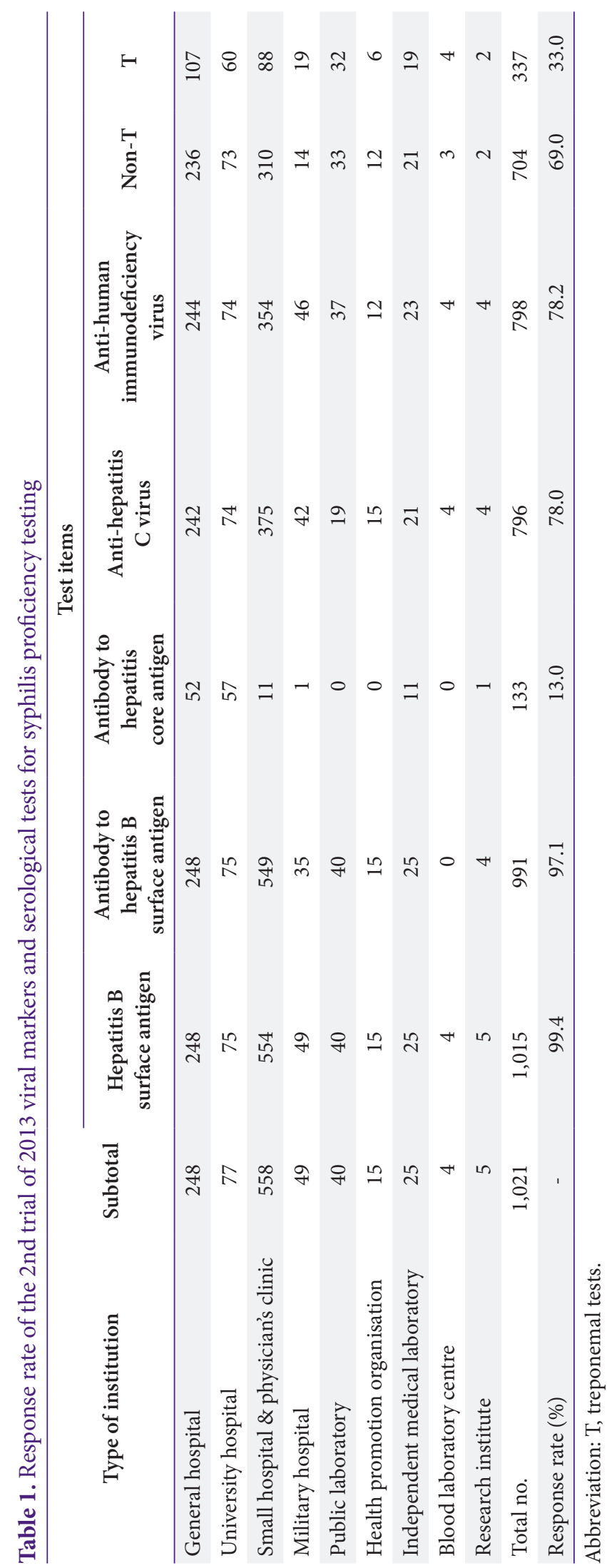




\section{4. 신빙도조사 검체의 균질성 및 안정성 평가}

신빙도조사 검체의 균질성은 조제 후 발송 전에 실시하였 는데, 병내균질성(intra-vial homogeneity)은 냉장보관하면 서 한 세트로 5 회 반복 측정하였고, 병간균질성 (inter-vial homogeneity)은 냉장보관하면서 5 세트로 1 회 측정하였다. 안정 성(stability)은 냉장보관하면서 제조당일, 발송 1-3주 전, 발 송 당일 및 발송 후 3 일로 분류한 뒤 각 검사종목을 측정하여 목표한 결과치가 유지되는지 검토하였다. 균질성 및 안정성 검 토에 사용된 시약 및 검사방법은 3종류 이상의 서로 다른 시약 과 장비로 확인하였다(Supplementary Table 1).

\section{5. 결과분석 및 통계}

결과는 인터넷 및 우편을 이용하여 접수하였고, 결과분석 은 각 검사종목별로 검사방법별(peer group) 결과와 전체 (total) 결과로 정리하였다. 통계처리는 Microsoft Excel 2010 (Microsoft, Redmond, WA, USA) 프로그램을 사용하였다.

\section{결과}

\section{1. 참여기관 및 회신율}

최소 1 종목 이상 신빙도조사에 참여한 기관들을 기준으로, 1 회차는 1,021 기관 중 1,019 기관이 회신하여 회신율 $99.8 \%$, 2 회차는 1,021 기관 중 1,020 기관이 회신하여 회신율 $99.9 \%$ 였 다. 2 차 신빙도조사를 기준으로 각 기관 유형별 참여현황 및 세부 종목별 참여현황은 Table 1에 정리하였다. 결과는 인터 넷 및 우편으로 접수하였는데, 1 차, 2 차 조사에서 회신한 모든 기관이 인터넷 접수로 회신하였다.

\section{2. 신빙도조사 검체의 균질성 및 안정성 결과}

신빙도조사 검체의 병내 및 병간균질성은 모두 변이계수 (CV)가 5\% 이내로 균질하게 제조되었음을 확인할 수 있었고 (Supplementary Table 2), 냉장 안정성 역시 제조 후 잘 유지 되고 있음을 확인하였다(Supplementary Fig. 1).

\section{3. 검사법 및 검사장비}

신빙도조사에 참여한 기관들의 검사종목별 검사방법 및 사 용장비는 결과보고지에 각 기관이 기재한 코드를 바탕으로 분 석하였다. 시약코드와 검사방법코드 또는 사용장비코드가 일 치하지 않는 경우 시약코드를 중심으로 분류하였고, 경우에 따 라서는 참여기관에 문의하여 확인한 후 수정하였다.

\section{1) 바이러스 항원 및 항체검사의 검사방법과 검사장비}

2차 신빙도조사를 기준으로 각 검사실에서 사용한 검사방 법을 정리해보면, $\mathrm{HBsAg}$ 및 anti-HBs검사는 각각 $74.1 \%$, $73.5 \%$ 의 기관이, anti- $\mathrm{HBc}$ 검사는 전 기관에서, anti-HCV 및 anti-HIV검사는 각각 $65.2 \%$ 와 $72.3 \%$ 의 기관이 효소 면역검사법(enzyme immunoassay, EIA), 미세입자효 소면역검사법(microparticle EIA), 화학발광면역검사법 (chemiluminescence immunoassay, CLIA), 전기화학발 광면역검사법(eletro-chemiluminescence immunoassay, ECLIA) 및 형광효소면역검사법(fluorescent enzyme immunoassay) 등 정량분석이 가능한 자동화 검사법으로 검 사를 실시하고 있었다. 정성분석법인 면역크로마토그래피법 (immunochromatography assay, ICA)은 HBsAg 및 anti$\mathrm{HBs}$ 검사에서는 각각 $25.9 \%, 26.5 \%$ 의 기관에서, anti-HCV

Table 2. Principles of methods measuring viral antigens or antibodies in the 2 nd trial of 2013 proficiency testing

\begin{tabular}{|c|c|c|c|c|c|}
\hline Method & $\begin{array}{c}\text { Hepatitis B } \\
\text { surface antigen }\end{array}$ & $\begin{array}{l}\text { Antibody to hepatitis } \\
\text { B surface antigen }\end{array}$ & $\begin{array}{l}\text { Antibody to hepatitis } \\
\text { core antigen }\end{array}$ & $\begin{array}{l}\text { Anti-hepatitis } \\
\text { C virus }\end{array}$ & $\begin{array}{c}\text { Anti-human } \\
\text { immunodeficiency virus }\end{array}$ \\
\hline EIA & $7(0.7)$ & $8(0.8)$ & & $23(2.9)$ & $23(2.9)$ \\
\hline CLIA & $377(37.1)$ & $371(37.4)$ & $88(66.2)$ & $307(38.6)$ & $320(40.1)$ \\
\hline ECLIA & $310(30.5)$ & $292(29.5)$ & $38(28.6)$ & $176(22.1)$ & $204(25.6)$ \\
\hline ICA & 263 (25.9) & $263(26.5)$ & & $277(34.8)$ & $220(27.6)$ \\
\hline RPHA/PHA/PA & & & & & $1(0.1)$ \\
\hline Total & $1,015(100.0)$ & $991(100.0)$ & $133(100.0)$ & $796(100.0)$ & $798(100.0)$ \\
\hline
\end{tabular}

Values are presented as number (\%).

Abbreviations: CLIA, chemiluminescence immunoassay; ECLIA, electrochemiluminescence immunoassay; EIA, enzyme immunoassay; FEIA, fluorescence enzyme immunoassay; ICA, immunochromatography assay; MEIA, microparticle enzyme immunoassay; PA, particle agglutination; PHA, passive hemagglutination; RIA, radioimmunoassay; RPHA, reversed passive hemagglutination. 
Journal of LABORATORY MEDICINE and QUALITY ASSURANCE

Jun Hyung Lee et al • EQA Report for Immunoserology (2013)

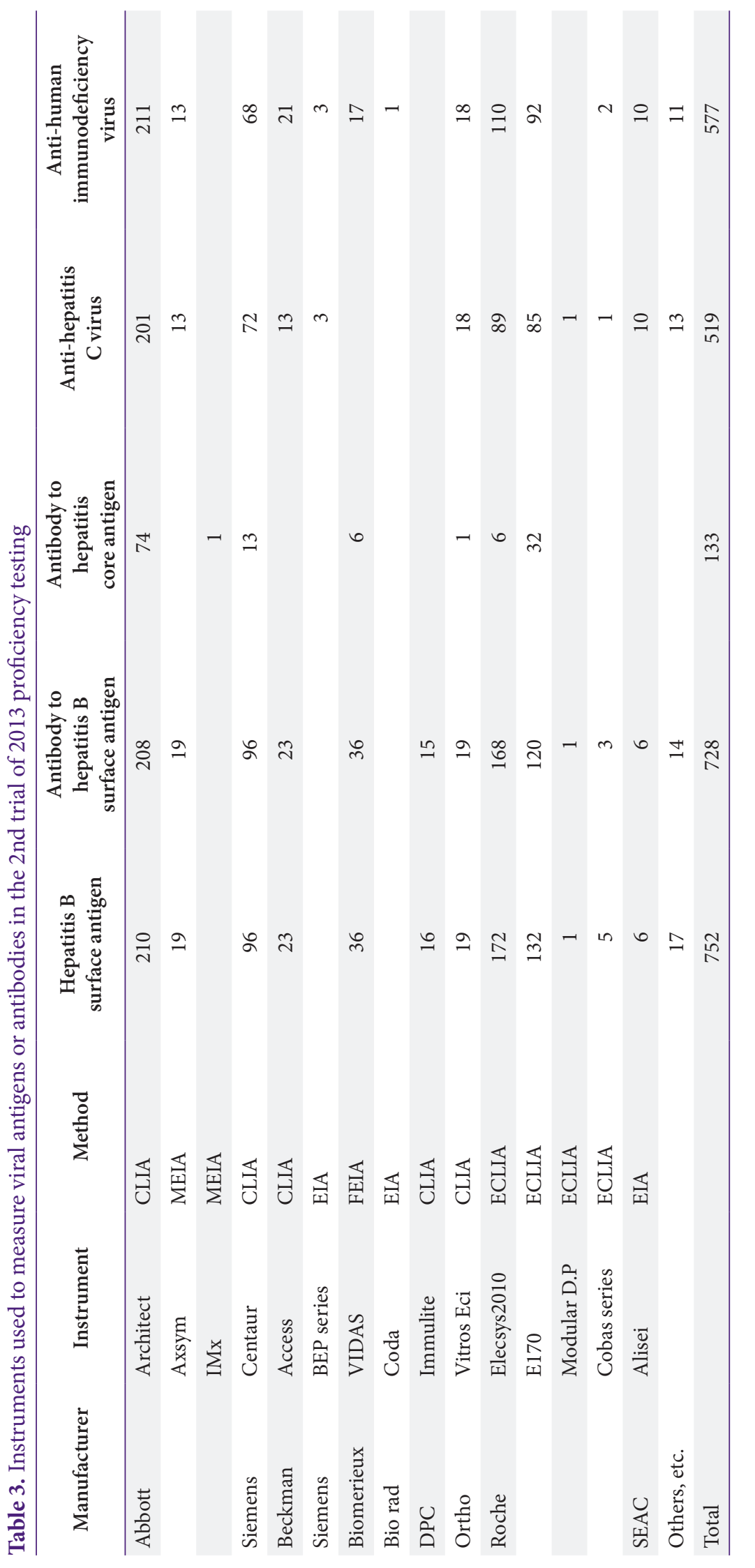


검사에서는 $34.8 \%$ 의 기관에서, anti-HIV검사에서는 $27.6 \%$ 의 기관에서 사용되고 있었다(Table 2). 검사장비별로 분류 해 보면 CLIA장비로는 Abbot사(Abbott Diagnostics, Abbott Park, IL, USA)의 Architect, Roche사(Roche Diagnostics $\mathrm{GmbH}$, Mannheim, Germany)의 Elecsys 2010과 E170, Siemens사(Siemens Healthcare Diagnostics, Tarrytown, NY, USA)의 Advia Centaur 등이 많이 사용되고 있었고, EIA장비로는 Biomerieux사(bioMérieux, Marcy l'Etoile, France)의 VIDAS, Abbott사의 Asxym장비 등이 많이 사용 되고 있었다(Table 3).

\section{2) 매독혈청검사방법}

비트레포네마(non-treponemal)검사는 rapid plasma reagin (RPR)법이 1, 2차 신빙도조사에서 각각 $74.0 \%, 71.3 \%$ 로 대부분의 기관에서 $\mathrm{RPR}$ 법을 사용하고 있었고, 정량검사 법인 혼탁면역측정법(turbidoimmunoassay, TIA)으로 보고 한 기관은 $23.3 \%, 26.7 \%$ 이었다(Table 4). Venereal Disease Research Laboratory법을 사용한 기관은 각각 $2.7 \%, 2.0 \%$ 였다. 트레포네마(treponemal)검사에서는 ICA법(45.7\%, 46.3\%)과 입자응집법(particle agglutination, PA)이 33.6\%, $32.6 \%$ 로 주로 이용되고 있었고, TIA 법은 $10.3 \%, 10.4 \%$ 의 기관에서 사용하고 있으며, 형광트레포네마항체흡수법

Table 4. Trend of methods for serologic tests for syphilis

\begin{tabular}{|c|c|c|c|c|c|c|c|}
\hline & \multirow{2}{*}{ Method } & \multicolumn{2}{|c|}{2011} & \multicolumn{2}{|c|}{2012} & \multicolumn{2}{|c|}{2013} \\
\hline & & 1st trial & 2nd trial & 1st trial & 2nd trial & 1st trial & 2nd trial \\
\hline \multirow[t]{4}{*}{ Non-treponemal } & RPR card & $547(80.7)$ & $546(78.2)$ & $535(76.2)$ & $516(74)$ & $522(74)$ & $502(71.3)$ \\
\hline & VDRL & $20(2.9)$ & $18(2.6)$ & $15(2.1)$ & $21(3)$ & $19(2.7)$ & $14(2)$ \\
\hline & TIA & $111(16.4)$ & $134(19.2)$ & $152(21.7)$ & $160(23)$ & $164(23.3)$ & $188(26.7)$ \\
\hline & Total & $678(100.0)$ & $698(100.0)$ & $702(100.0)$ & $697(100.0)$ & $705(100.0)$ & $704(100.0)$ \\
\hline \multirow[t]{7}{*}{ Treponemal } & TPHA & $54(16.4)$ & $17(5.1)$ & $13(4)$ & $13(3.8)$ & $8(2.4)$ & $5(1.5)$ \\
\hline & $\mathrm{PA}$ & $77(23.4)$ & $116(35)$ & $120(36.6)$ & $116(34.1)$ & $114(33.6)$ & $110(32.6)$ \\
\hline & FTA-ABS & $6(1.8)$ & $8(2.4)$ & $5(1.5)$ & $6(1.8)$ & $5(1.5)$ & $6(1.8)$ \\
\hline & ICA & $133(40.4)$ & $140(42.3)$ & $139(42.4)$ & $148(43.5)$ & $155(45.7)$ & $156(46.3)$ \\
\hline & CLIA & $19(5.8)$ & $19(5.7)$ & $21(6.4)$ & $20(5.9)$ & $22(6.5)$ & $25(7.4)$ \\
\hline & TIA & $40(12.2)$ & $31(9.4)$ & $30(9.1)$ & 37 (10.9) & $35(10.3)$ & $35(10.4)$ \\
\hline & Total & $329(100.0)$ & $331(100.0)$ & $328(100.0)$ & $340(100.0)$ & $339(100.0)$ & $337(100.0)$ \\
\hline
\end{tabular}

Values are presented as number (\%).

Abbreviations: FTA-ABS, fluorescent treponemal antibody absorption; RPR, rapid plasma reagin; TIA, turbidoimmunoassay; TPHA, treponema pallidum hemagglutination; VDRL, venereal disease research laboratory.

Table 5. Proficiency testing results for HBsAg in 2013

\begin{tabular}{|c|c|c|c|c|c|c|c|c|c|c|c|c|c|c|c|c|c|c|c|c|}
\hline \multirow{3}{*}{ Method } & \multicolumn{10}{|c|}{ 1st trial } & \multicolumn{10}{|c|}{ 2nd trial } \\
\hline & \multicolumn{5}{|c|}{ HBsAg (13-S-3) } & \multicolumn{5}{|c|}{ HBsAg (13-S-4) } & \multicolumn{5}{|c|}{ HBsAg (13-S-8) } & \multicolumn{5}{|c|}{ HBsAg (13-S-9) } \\
\hline & $\mathrm{N}$ & WP & $P$ & SP & Total & $\mathbf{N}$ & WP & $P$ & SP & Total & $\mathbf{N}$ & WP & $P$ & SP & Total & $\mathrm{N}$ & WP & $P$ & SP & Total \\
\hline EIA & & & 6 & 1 & 7 & 7 & & & & 7 & & & 5 & 2 & 7 & 7 & & & & 7 \\
\hline MEIA & 2 & & 22 & & 24 & 23 & & 1 & & 24 & & 1 & 17 & 1 & 19 & 19 & & & & 19 \\
\hline CLIA & & & 323 & 54 & 377 & 373 & 2 & 2 & & 377 & 1 & & 324 & 52 & 377 & 356 & 5 & 16 & & 377 \\
\hline FEIA & & 1 & 32 & 3 & 36 & 36 & & & & 36 & & & 34 & 5 & 39 & 39 & & & & 39 \\
\hline ECLIA & & & 263 & 41 & 304 & 299 & 1 & 4 & & 304 & & & 258 & 52 & 310 & 308 & 1 & 1 & & 310 \\
\hline ICA & 1 & 8 & 248 & 7 & 264 & 264 & & & & 264 & 1 & & 248 & 14 & 263 & 261 & 2 & & & 263 \\
\hline Total & 3 & 9 & 894 & 106 & 1,012 & 1,002 & 3 & 7 & & 1,012 & 2 & 1 & 886 & 126 & 1,015 & 990 & 8 & 17 & & 1,015 \\
\hline
\end{tabular}

Abbreviations: HBsAg, Hepatitis B surface antigen; N, negative; WP, weakly positive; P, positive; SP, strongly positive. 
(fluorescent treponemal antibody-absorption) 등은 소수의 기관 $(1.5 \%, 1.8 \%)$ 에서만 실시되고 있었다.

\section{4. 종목별 결과분석}

개별 종목별 결과는 검사법에 따라 분류하여 정리하였다.

1) Hepatitis $B$ surface antigen

$\mathrm{HBsAg}$ 검사에 대한 신빙도조사결과, 1 차의 $13-\mathrm{S}-3$ 검체와 2차의 13-S-8 검체는 양성 검체로 각각 1,012 기관 중 1,019 기관, 1,015 기관 중 1,013 기관에서 양성으로 보고하여 각각 $99.7 \%$ 와 $99.8 \%$ 의 높은 일치율을 보였다(Table 5). 한편 1 차의 $13-\mathrm{S}-4$ 검체와 2 차의 $13-\mathrm{S}-9$ 검체는 음성 검체로 각각 1,012 기관 중 1,002 기관, 1,015 기관 중 990 기관에서 음성으로 보고하여 각각 $99.0 \%, 97.5 \%$ 의 일치율을 보였다.

\section{2) Antibody to hepatitis B surface antigen}

Anti-HBs검사에 대한 신빙도조사결과, 1 차의 $13-\mathrm{S}-3$ 검 체와 2차의 13-S-8 검체는 음성 검체로 각각 990 기관 중 978
기관, 991 기관 중 960 기관이 음성으로 보고하여 각각 $98.8 \%$, $96.9 \%$ 의 일치율을 보였다. 또한 1차의 $13-\mathrm{S}-4$ 검체와 $13-\mathrm{S}-9$ 검체는 양성 검체로 각각 990 기관 중 987, 991기관 중 990기 관이 양성으로 보고하여 각각 $99.7 \%, 99.9 \%$ 의 일치율을 보였 다(Table 6).

\section{3) Antibody to hepatitis core antigen}

$\mathrm{Anti}-\mathrm{HBc}$ 검사에 대한 신빙도조사결과, 1 차의 $13-\mathrm{S}-3$ 검 체와 2차의 13-S-8 검체는 비교적 강한 양성으로 각각 136, 133 개 기관에서 모두 양성으로 보고하여 $100 \%$ 의 일치율을 보였다. 한편 1차의 $13-\mathrm{S}-4$ 검체는 음성 검체였고, 2차의 13S-9 검체는 약양성 검체로 각각 99.3\% (135/136)와 100\% (133/133)의 일치율을 보였다(Table 7).

\section{4) Anti-hepatitis $C$ virus}

Anti-HCV검사에 대한 신빙도조사결과, 1차의 13-S-3와 2 차의 $13-\mathrm{S}-8$ 은 양성 검체로 각각 798기관 중 786기관, 796 기 관 중 790 기관에서 약양성 이상으로 보고하여 각각 $98.5 \%$,

Table 6. Proficiency testing results for anti-HBs in 2013

\begin{tabular}{|c|c|c|c|c|c|c|c|c|c|c|c|c|c|c|c|c|c|c|c|c|}
\hline \multirow{3}{*}{ Method } & \multicolumn{10}{|c|}{ 1st trial } & \multicolumn{10}{|c|}{ 2nd trial } \\
\hline & \multicolumn{5}{|c|}{ Anti-HBs (13-S-3) } & \multicolumn{5}{|c|}{ Anti-HBs (13-S-4) } & \multicolumn{5}{|c|}{ Anti-HBs (13-S-8) } & \multicolumn{5}{|c|}{ Anti-HBs (13-S-9) } \\
\hline & $\mathrm{N}$ & WP & $\mathrm{P}$ & SP & Total & $\mathbf{N}$ & WP & $\mathrm{P}$ & SP & Total & $\mathbf{N}$ & WP & $\mathrm{P}$ & SP & Total & $\mathrm{N}$ & WP & $\mathrm{P}$ & SP & Total \\
\hline EIA & 8 & & & & 8 & & & 8 & & 8 & 8 & & & & 8 & & & 7 & 1 & 8 \\
\hline MEIA & 24 & & & & 24 & & & 23 & 1 & 24 & 19 & & & & 19 & & & 19 & & 19 \\
\hline CLIA & 360 & & 12 & & 372 & & & 365 & 7 & 372 & 342 & 4 & 24 & 1 & 371 & & & 331 & 40 & 371 \\
\hline FEIA & 36 & & & & 36 & & & 30 & 6 & 36 & 36 & 1 & 1 & & 38 & & & 28 & 10 & 38 \\
\hline ECLIA & 286 & & & & 286 & 2 & & 272 & 12 & 286 & 292 & & & & 292 & & & 231 & 61 & 292 \\
\hline ICA & 264 & & & & 264 & 1 & 12 & 250 & 1 & 264 & 263 & & & & 263 & 1 & 1 & 250 & 11 & 263 \\
\hline Total & 978 & & 12 & & 990 & 3 & 12 & 948 & 27 & 990 & 960 & 5 & 25 & 1 & 991 & 1 & 1 & 866 & 123 & 991 \\
\hline
\end{tabular}

Abbreviations: Anti-HBs, antibody to hepatitis B surface antigen; N, negative; WP, weakly positive; P, positive; SP, strongly positive.

Table 7. Proficiency testing results for anti-HBc in 2013

\begin{tabular}{|c|c|c|c|c|c|c|c|c|c|c|c|c|c|c|c|c|c|c|c|c|}
\hline \multirow{3}{*}{ Method } & \multicolumn{10}{|c|}{ 1st trial } & \multicolumn{10}{|c|}{ 2nd trial } \\
\hline & \multicolumn{5}{|c|}{ Anti-HBc (13-S-3) } & \multicolumn{5}{|c|}{ Anti-HBc (13-S-4) } & \multicolumn{5}{|c|}{ Anti-HBc (13-S-8) } & \multicolumn{5}{|c|}{ Anti-HBc (13-S-9) } \\
\hline & $\mathrm{N}$ & WP & $\mathrm{P}$ & SP & Total & $\mathbf{N}$ & WP & $\mathbf{P}$ & SP & Total & $\mathrm{N}$ & WP & $\mathbf{P}$ & SP & Total & $\mathbf{N}$ & WP & $\mathbf{P}$ & SP & Total \\
\hline MEIA & & & 1 & & 1 & 1 & & & & 1 & & & 1 & & 1 & & & 1 & & 1 \\
\hline CLIA & & & 87 & 1 & 88 & 88 & & & & 88 & & & 88 & & 88 & & 2 & 86 & & 88 \\
\hline FEIA & & & 8 & & 8 & 8 & & & & 8 & & & 6 & & 6 & & & 6 & & 6 \\
\hline ECLIA & & & 39 & & 39 & 38 & & 1 & & 39 & & & 38 & & 38 & & & 38 & & 38 \\
\hline Total & & & 135 & 1 & 136 & 135 & & 1 & & 136 & & & 133 & & 133 & & 2 & 131 & & 133 \\
\hline
\end{tabular}

Abbreviations: Anti-HBc, antibody to hepatitis core antigen; N, negative; WP, weakly positive; P, positive; SP, strongly positive. 
$99.2 \%$ 의 일치율을 보였다. 1 차의 $13-\mathrm{S}-4$ 검체와 2 차의 $13-\mathrm{S}-$ 9 검체는 음성 검체로 각각 798 기관 중 793 기관, 796 기관 중 793 기관에서 음성으로 보고하여 각각 $99.4 \%, 99.6 \%$ 의 일치 율을 보였다(Table 8). 특히 1차의 13-S-3 검체와 2차의 13S-8번 검체는 양성으로 제조되었으나, 음성으로 결과를 보고 한 기관들이 있었는데, 이들 기관 중 1 차에서는 12 기관 모두 (100\%), 2차는 6기관 중 5기관(83.3\%)에서 ICA법을 사용하 고 있었다.

\section{5) Anti-human immunodeficiency virus}

Anti-HIV검사에 대한 신빙도조사결과, 1차의 13-S-3 검체 와 2차의 13-S-8 검체는 음성 검체로 각각 792기관 중 767기 관, 798 기관 중 788 기관에서 음성으로 보고하여 각각 $96.8 \%$, $98.7 \%$ 의 일치율을 보였다. 또한 1차의 $13-\mathrm{S}-4$ 과 2차의 $13-\mathrm{S}-$ 9 검체는 양성 검체로 각각 792 기관 중 788 기관, 798 기관 중 793 기관에서 약양성 이상으로 보고하여 각각 $99.5 \%, 99.4 \%$
의 일치율을 보였다(Table 9).

\section{6) Serologic test for syphilis}

STS검사 신빙도조사결과, 1 차의 $13-\mathrm{S}-5$ 검체는 양성 검체 로 비트레포네마검사에서는 705 기관 중 623 기관에서 약양성 이상으로 보고하였고, 트레포네마검사에서는 339기관 중 337 기관에서 양성의 결과를 보고하여 각각 $88.4 \%$ 와 $99.4 \%$ 의 일 치율을 보였다. 2차의 13-S-10 검체 또한 양성 검체로 비트레 포네마검사에서는 704 기관 중 690 기관에서 약양성 이상의 결 과를 보였고, 트레포네마검사에서는 337기관 중 333기관에서 약양성 이상의 결과를 보고하여 각각 $98.0 \%, 98.8 \%$ 의 일치율 을 보였다(Table 10). 특히 1차의 13-S-5 검체에 대한 비트레 포네마검사에서 음성으로 보고한 기관이 많았는데, 특정 시약 을 사용하는 기관에서 주로 음성결과를 보고하였다.

Table 8. Proficiency testing results for anti-HCV in 2013

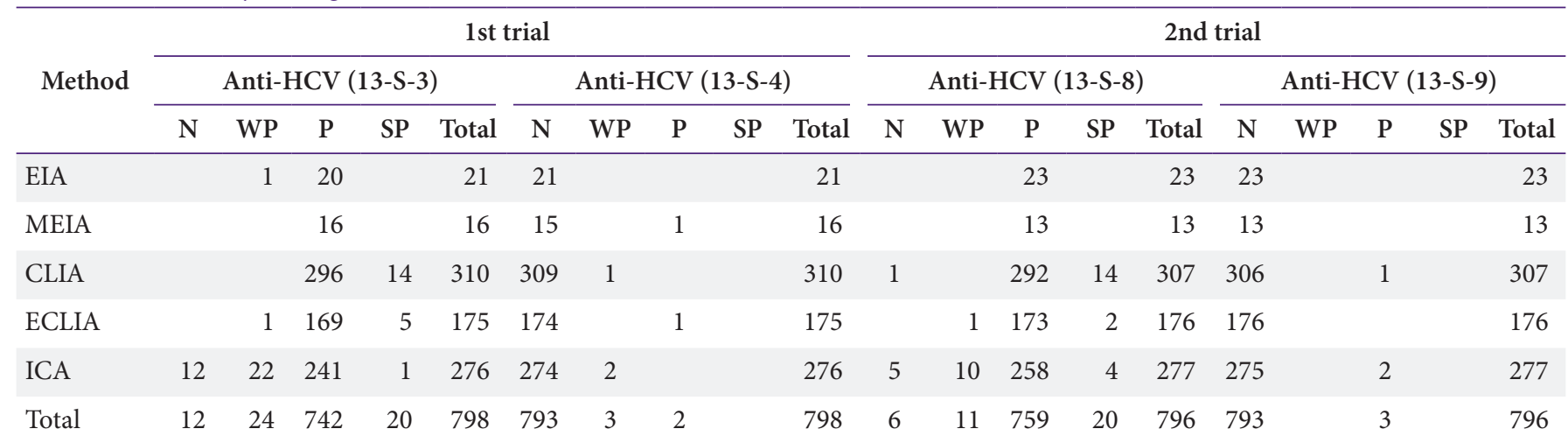

Abbreviations: Anti-HCV, anti-hepatitis $\mathrm{C}$ virus; N, negative; WP, weakly positive; $\mathrm{P}$, positive; SP, strongly positive.

Table 9. Proficiency testing results for anti-HIV in 2013

\begin{tabular}{|c|c|c|c|c|c|c|c|c|c|c|c|c|c|c|c|c|c|c|c|c|}
\hline \multirow{3}{*}{ Method } & \multicolumn{10}{|c|}{ 1st trial } & \multicolumn{10}{|c|}{ 2nd trial } \\
\hline & \multicolumn{5}{|c|}{ Anti-HIV (13-S-3) } & \multicolumn{5}{|c|}{ Anti-HIV (13-S-4) } & \multicolumn{5}{|c|}{ Anti-HIV (13-S-8) } & \multicolumn{5}{|c|}{ Anti-HIV (13-S-9) } \\
\hline & $\mathrm{N}$ & WP & $P$ & SP & Total & $\mathrm{N}$ & WP & $P$ & SP & Total & $\mathrm{N}$ & WP & $\mathbf{P}$ & SP & Total & $\mathrm{N}$ & WP & $\mathbf{P}$ & SP & Total \\
\hline EIA & 22 & & & & 22 & & & 21 & 1 & 22 & 23 & & & & 23 & & & 22 & 1 & 23 \\
\hline MEIA & 17 & & & & 17 & 1 & & 16 & & 17 & 13 & & & & 13 & & & 13 & & 13 \\
\hline CLIA & 295 & 1 & 23 & & 319 & & 1 & 299 & 19 & 319 & 312 & 1 & 7 & & 320 & 1 & & 304 & 15 & 320 \\
\hline FEIA & 19 & & & & 19 & & & 18 & 1 & 19 & 17 & & & & 17 & & & 14 & 3 & 17 \\
\hline ECLIA & 199 & & & & 199 & 1 & & 188 & 10 & 199 & 204 & & & & 204 & & & 176 & 28 & 204 \\
\hline ICA & 213 & 1 & & & 214 & 2 & 4 & 200 & 8 & 214 & 218 & 1 & 1 & & 220 & 4 & 2 & 207 & 7 & 220 \\
\hline PA & 2 & & & & 2 & & & 2 & & 2 & 1 & & & & 1 & & & 1 & & 1 \\
\hline Total & 767 & 2 & 23 & & 792 & 4 & 5 & 744 & 39 & 792 & 788 & 2 & 8 & & 798 & 5 & 2 & 737 & 54 & 798 \\
\hline
\end{tabular}

Abbreviations: Anti-HIV, anti-human immunodeficiency virus; N, negative; WP, weakly positive; P, positive; SP, strongly positive. 
Journal of LABORATORY MEDICINE and QUALITY ASSURANCE

Jun Hyung Lee et al • EQA Report for Immunoserology (2013)

Table 10. Proficiency testing results for STS in 2013

\begin{tabular}{|c|c|c|c|c|c|c|c|c|c|}
\hline \multirow{2}{*}{\multicolumn{2}{|c|}{ Method }} & \multicolumn{4}{|c|}{ STS (13-S-5) } & \multicolumn{4}{|c|}{ STS (13-S-10) } \\
\hline & & \multirow{2}{*}{$\begin{array}{r}\text { NR } \\
33\end{array}$} & \multirow{2}{*}{$\begin{array}{r}\text { WR } \\
35\end{array}$} & \multirow{2}{*}{$\begin{array}{r}\mathbf{R} \\
454\end{array}$} & \multirow{2}{*}{\begin{tabular}{c|} 
Total \\
522
\end{tabular}} & \multirow{2}{*}{$\begin{array}{c}\text { NR } \\
12\end{array}$} & \multirow{2}{*}{$\begin{array}{c}\text { WR } \\
16\end{array}$} & \multirow{2}{*}{$\begin{array}{c}\mathrm{R} \\
474\end{array}$} & \multirow{2}{*}{$\begin{array}{c}\text { Total } \\
502\end{array}$} \\
\hline Non-treponemal & RPR card & & & & & & & & \\
\hline & VDRL & 2 & & 17 & 19 & 2 & & 12 & 14 \\
\hline & TIA & 47 & 4 & 113 & 164 & & 2 & 186 & 188 \\
\hline & Subtotal & 82 & 39 & 584 & 705 & 14 & 18 & 672 & 704 \\
\hline \multirow[t]{7}{*}{ Treponemal } & TPHA & & & 8 & 8 & & & 5 & 5 \\
\hline & $\mathrm{PA}$ & & & 114 & 114 & 1 & & 109 & 110 \\
\hline & FTA-ABS & & & 5 & 5 & & & 6 & 6 \\
\hline & ICA & & & 155 & 155 & 3 & 23 & 156 & 156 \\
\hline & CLIA & & & 22 & 22 & & & 25 & 25 \\
\hline & TIA & 2 & & 33 & 35 & & & 35 & 35 \\
\hline & Subtotal & 2 & & 337 & 339 & 4 & 23 & 310 & 337 \\
\hline Total & & 84 & 376 & 921 & 1,044 & 18 & 42 & 982 & 1,041 \\
\hline
\end{tabular}

Abbreviations: STS, serologic tests for syphilis; N, negative; WP, weakly positive; P, positive; SP, strongly positive.

\section{고찰}

면역혈청분과위원회의 2013년 바이러스 항원/항체 및 STS 신빙도조사사업은 5 월과 11 월에 실시되었는데, 총 1,021 기관 에 검체를 발송하여 1,2 차에 모두 참여한 기관이 1,019 기관 (99.8\%)으로 매우 높은 참여율을 보였다. 2013년 참여기관은 총 1,020 기관으로 2012 년에 비하여 16 기관(1.6\%)이 증가하 여 전년도에 비하여 증가율은 다소 둔화되었다[6]. 신빙도조 사에 사용되는 검체는 matrix effect를 배제하기 위해 '인체유 래 고위험군바이러스 소재은행'인 '혈청검체은행'으로부터 검 증받은 혈청을 분양받아 각 종목의 양성과 음성 정도관리 검체 를 인간혈청으로 자가제조하였고 병내균질성, 병간균질성 및 안정성을 검증하여 발송하였다.

바이러스 항원 및 항체검사에 대한 신빙도조사결과 $\mathrm{HBsAg}$, anti-HBs 종목은 2011년부터 전통적 방법인 RPHA, PHA법 및 RIA법이 시약 단종과 더불어 CLIA 및 ECLIA법으로 이전 되는 현상을 보였다. 2013년 신빙도조사에서는 특히 CLIA법 의 위양성이 많이 발견되었는데, anti-HIV의 경우에는 1 차에 서 음성으로 제조된 13-S-3번 검체를 양성으로 보고한 25기관 중 24기관(96\%)이 CLIA법을 사용하였고, 그 외 2차 13-S-9 검체에서 실시한 HBsAg, $13-\mathrm{S}-8$ 검체에서 실시한 anti-HBs 종목에서도 CLIA법에서 위양성이 다수 발견되었다. CLIA법 에서의 위양성의 원인은 검사법의 민감도(sensitivity)와 관련 이 있을 것으로 생각되고, 한편으로는 혈장을 혈청으로 전환하 는 과정에서 생성된 혼탁에 의한 영향을 우려하여 보관된 검체
로 여러 차례 검증을 실시하였으나 검체에서 이상이 발견되지 는 않았다.

간이검사법인 ICA법을 사용하는 경우 양성 검체에서 위음 성의 결과를 보인 경우가 있었는데, anti-HCV 종목에서 1차 에서 13-S-3 검체에서 위음성을 보인 12 기관은 모두 ICA법을 사용하고 있었고, 2차에서는 13-S-8 검체에서 위음성을 보인 6 기관 중 5 기관(83.3\%)에서 ICA법을 사용하고 있었다. ICA 법의 위음성의 결과는 해당 검사법 자체의 민감도가 낮기 때문 인 것으로 생각되며, ICA법의 경우 검사 시 판독시간 및 기준, 시약의 변질이나 보관상태(습기 차단, 밀봉 여부) 등도 결과에 중요한 영향을 미치고, 제품에 따라 로트별로 결과에 차이가 발생하는 경우도 관찰되므로 이와 같은 요인들에 주의가 필요 하다.

STS 중 비트레포네마검사는 RPR법이 71-74\% 정도로 아 직까지 가장 많이 사용되고 있는 방법이고, 최근 소개된 TIA 법의 경우 2012년도에는 23\% 사용하고 있었는데, 2013년도 $27 \%$ 의 기관에서 사용하는 등 전년도와 비교할 때 서서히 증 가하고 있는 양상이었다[6]. TIA법으로 시행하는 정량검사법 의 경우 실제 정량검사를 시행하면서도 이전의 검사법으로 보 고한 기관을 포함하면 상당수의 기관에서 정량검사법을 사용 하는 것으로 생각된다. 그러나 1 차의 비트레포네마검사에서 특정 제품의 TIA를 사용하는 기관에서 특히 위음성 결과가 많 이 발생하였는데, 이렇게 비트레포네마검사에서 위음성을 보 일 수 있는 상황은 매독의 활성도가 매우 높은 제 2 기 매독, 조 기잠복매독, 신경매독 등에서 고역가에 의한 전지대(prozone) 
현상이 발생하는 경우, 후기 매독에서 cardiolipin 항체가 점 차 감소하여 음성으로 나타나는 경우, HIV 감염 또는 다른 이 유로 인한 면역억제상태에서 항체생성 장애로 음성으로 나타 나는 경우 등이 있다[7]. 저자들은 상기 원인들을 의심하고 조 사하였으나 그 원인을 정확히 밝히지는 못하여, 1 차의 비트레 포네마검사는 기관 평가에서는 제외하였다. 트레포네마검사 에서는 고전적 방법인 $\mathrm{TPHA}$ 법이 감소하고, $45 \%$ 를 상회하는 기관이 ICA법으로 보고하여 ICA법이 가장 많이 사용되고 있 었고, PA법, TIA법 및 CLIA법은 그 사용이 꾸준히 증가하고 있었다. 트레포네마검사의 일치율은 2012년에 이어 2013년도 에도 향상된 결과를 보였다. 즉 1차에서는 $99.4 \%, 2$ 차에서도 $98.8 \%$ 기관에서 일치된 결과를 보였다. 이는 본 분과에서 시 행했던 워크샵과 결과보고서를 통하여 결과 판독의 특성상 검 사자의 주관이 결과 판독에 많은 영향을 주게 되므로 검사기관 에서는 보다 객관적인 판독기준을 수립하여 판독에 오류가 없 도록 주지시킨 결과가 아닌가 생각된다.

신빙도조사의 결과 처리를 위하여 검사결과, 방법, 시약 및 기기를 코드화하여 결과를 보고하도록 하고 있는데, 검사기관 에게 보고한 표기가 정확하지 않아 분석에 많은 어려움이 있었 다. 이러한 사무적 오차 역시 정도관리의 한 부분이므로 각 기 관에서는 결과 입력 시 좀 더 주의를 기해야 할 것으로 생각된다.

\section{면역혈청분과 위원(2013)}

차영주(위원장, 중앙대학교 의과대학), 배재훈(간사, 중앙 대학교병원), 권소영(대한적십자사), 김신규(한양대학교 의과 대학), 김재룡(계명대학교 의과대학), 김현숙(연세대학교 의 과대학), 박성훈(영남대병원), 박애자(중앙대학교 의과대학), 채석래(동국대학교 의과대학), 조윤정(고려대학교 의과대학), 박규은(중앙대학교 의과대학)

\section{SUPPLEMENTARY MATERIALS}

Supplementary materials can be found via http://
pdf.medrang.co.kr/LMQA/2014/036/LMQA036-04-01_ Supple0.pdf

\section{REFERENCES}

1. Cha YJ, Kwon SY, Kim TY, Kim JR, Kim HS, Park MH, et al. Annual report on external quality assessment in immunoserology in Korea (2009). J Lab Med Qual Assur 2010;32:45-68.

2. Cha YJ, Kwon SY, Kim TY, Kim JR, Kim HS, Park MH, et al. Annual report on external quality assessment in immunoserology in Korea (2005). J Lab Med Qual Assur 2006;28:41-61.

3. Cha YJ, Kwon SY, Kim TY, Kim JR, Kim HS, Park MH, et al. Annual report on external quality assessment in immunoserology in Korea (2006). J Lab Med Qual Assur 2007;29:45-64.

4. Cha YJ, Kwon SY, Kim TY, Kim JR, Kim HS, Park MH, et al. Annual report on external quality assessment in immunoserology in Korea (2007). J Lab Med Qual Assur 2008;30:49-74.

5. Cha YJ, Kwon SY, Kim TY, Kim JR, Kim HS, Park MH, et al. Annual report on external quality assessment in immunoserology in Korea (2008). J Lab Med Qual Assur 2009;31:49-72.

6. Cha YJ, Kwon SY, Kim TY, Kim JR, Kim HS, Park MH, et al. Annual report on external quality assessment in immunoserology in Korea (2012). J Lab Med Qual Assur 2013;34:51-89.

7. Goh BT, van Voorst Vader PC; European Branch of the International Union against Sexually Transmitted Infection and the European Office of the World Health Organization. European guideline for the management of syphilis. Int J STD AIDS 2001;12 Suppl 3:14-26. 


\section{바이러스 항원/항체 및 매독혈청검사 신빙도조사 결과보고} (2013)

\section{이준형 - 차영주 $^{1} \bullet$ 배재훈 $^{1}$ - 채석래 ${ }^{2}$ - 대한임상검사정도관리협회 면역혈청분 과위원회 \\ 중앙대학교병원 진단검사의학과, ${ }^{2}$ 동국대학교 일산병원 진단검사의학과}

대한임상검사정도관리협회 면역혈청분과위원회의 2013년 바이러스 항원/항체 및 매독혈청검사 (serologic test for syphilis, STS) 신빙도조사사업은 5월과 11월에 2회에 걸쳐 시행되었다. 각 회 차마다 3 개의 혼주혈청 검체를 총 1,021 기관에 검체를 발송하였다. 신빙도조사용 검체는 제조 당일 부터 발송 3일 후까지 3종류 이상의 검사방법으로 균질성과 안정성에 대한 검증을 실시하였다. 참여

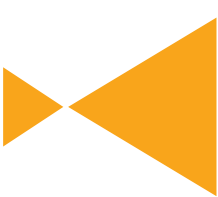

Journal of

LABORATORY MEDICINE

and

QUALITY ASSURANCE 기관은 1회차에 1,019기관(99.8\%), 2회차 1,020기관(99.9\%)이었다. 바이러스 항원/항체 및 STS 중 hepatitis B surface antigen에 가장 많은 기관이 참여하였고, antibody to hepatitis B surface antigen, anti-human immunodeficiency virus, anti-hepatitis C virus, STS, 및 antibody to hepatitis core antigen 순으로 참여하였다. 바이러스 항원/항체검사 신빙도조사결과 가장 많이 사 용되고 있는 전기화학발광면역검사법을 포함한 화학발광면역검사법에서는 약간의 위양성 결과가 발 생하였고, 근래 사용이 증가하고 있는 면역크로마토그래피법에서는 위음성 결과에 주의하여야 할 것 으로 분석되었다. 한편 최근 STS에서는 혼탁면역검사법과 화학발광면역검사법 등 새로운 검사법이 소개되어 그 사용이 점차 증가하고 있다.

(J Lab Med Qual Assur 2014;36:161-170)

\section{교신저자: 차영주}

우)156-861 서울시 동작구 흑석로 84, 중앙대학교 의과대학 진단검사의학교실

Tel: 02)6299-2720, Fax: 02)6298-8630, E-mail: chayoung@cau.ac.kr 


\title{
Annual Report on External Quality Assessment of Viral Markers and Serological Tests for Syphilis in Korea (2013)
}

\author{
Jun Hyung Lee ${ }^{1}$, Young Joo Cha ${ }^{1}$, Jae Hoon Bae ${ }^{1}$, and Seok Lae Chae ${ }^{2}$, \\ as Immunoserology Subcommittee, The Korean Association \\ of Quality Assurance for Clinical Laboratory \\ ${ }^{1}$ Department of Laboratory Medicine, Chung-Ang University College of Medicine, Seoul; \\ ${ }^{2}$ Department of Laboratory Medicine, Dongguk University Ilsan Hospital, \\ Dongkuk University College of Medicine, Goyang, Korea
}


Supplementary Table 1. Methods used for checking homogeneity and stability of control specimens

\begin{tabular}{llll}
\hline Test items & Methods & Instruments & Reagents \\
\hline Viral antigen or antibody & ECLIA & E170, Roche & Reagent for E170 \\
& CLIA & Architect, Abbott & Reagent for Architect \\
& Centaur XP, Siemens & Reagent for Centaur XP \\
Non-treponemal test & Manual & SD/Green Cross MS/Asan device kit \\
& TIA & AU5400, Beckman & Mediace RPR \\
VDRL & Manual & BD VDRL Antigen for syphilis serology \\
RPR & & Asan RPR card test \\
& & IVD Labslide RPR \\
Treponemal test & AUS5400, Beckman & BD Macro-Vue RPR card test \\
& TPPA & Manual & Mediace TPLA \\
ICA & Manual & SERODIA-TPPA \\
& & SD Syphilis 3.0 kit \\
& & Asan Easy test Syphilis \\
& & Humasis Syphilis card \\
& & HBI Syphilis card \\
& & Biofocus Syphilis card \\
\hline
\end{tabular}

Abbreviations: CLIA, chemiluminescence immunoassay; ECLIA, electrochemiluminescence immunoassay; ICA, immunochromatography assay; RPR, rapid plasma reagin; TIA, turbidoimmunoassay; TPPA, treponema pallidum particle agglutination assay; VDRL, venereal disease research laboratory. 
Supplementary Table 2. Intra-vial and inter-vial homogeneity of control specimens

\begin{tabular}{|c|c|c|c|c|c|c|c|}
\hline \multirow{2}{*}{ Trial } & \multirow{2}{*}{ Test items } & \multirow{2}{*}{ Sample } & \multirow{2}{*}{ Mean ${ }^{*}$} & \multicolumn{4}{|l|}{$\mathrm{CV}(\%)$} \\
\hline & & & & Intra-vial & & & \\
\hline \multirow[t]{5}{*}{1 st } & HBsAg & $13-S-3$ & $2,213.87$ & & 3.1 & 3.7 & 3.4 \\
\hline & Anti-HBs & $13-S-4$ & 299.09 & & 2.1 & 1.6 & 1.9 \\
\hline & Anti-HCV & $13-S-3$ & 9.58 & & 2.4 & 2.4 & 2.4 \\
\hline & Anti-HIV & $13-S-4$ & 63.71 & & 2.8 & 3.0 & 2.9 \\
\hline & Anti-TP & $13-S-5$ & 319.70 & & 1.4 & 0.8 & 1.2 \\
\hline \multirow[t]{5}{*}{ 2nd } & HBsAg & $13-S-8$ & $2,407.19$ & & 1.2 & 3.5 & 2.6 \\
\hline & Anti-HBs & $13-S-9$ & 687.65 & & 2.6 & 3.5 & 3.1 \\
\hline & Anti-HCV & $13-S-8$ & 11.99 & & 1.6 & 2.0 & 1.8 \\
\hline & Anti-HIV & $13-S-9$ & 191.32 & & 2.2 & 2.7 & 2.5 \\
\hline & Anti-TP & $13-S-10$ & 56.50 & & 1.4 & 4.9 & 3.6 \\
\hline
\end{tabular}

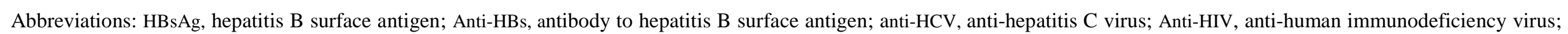

Anti-TP, antibody to treponema pallidum.

*Units are signal to cut-off ratio in HBsAg, Anti-HCV, Anti-HIV; IU/L in Anti-HBs; treponemal unit in Anti-TP. 

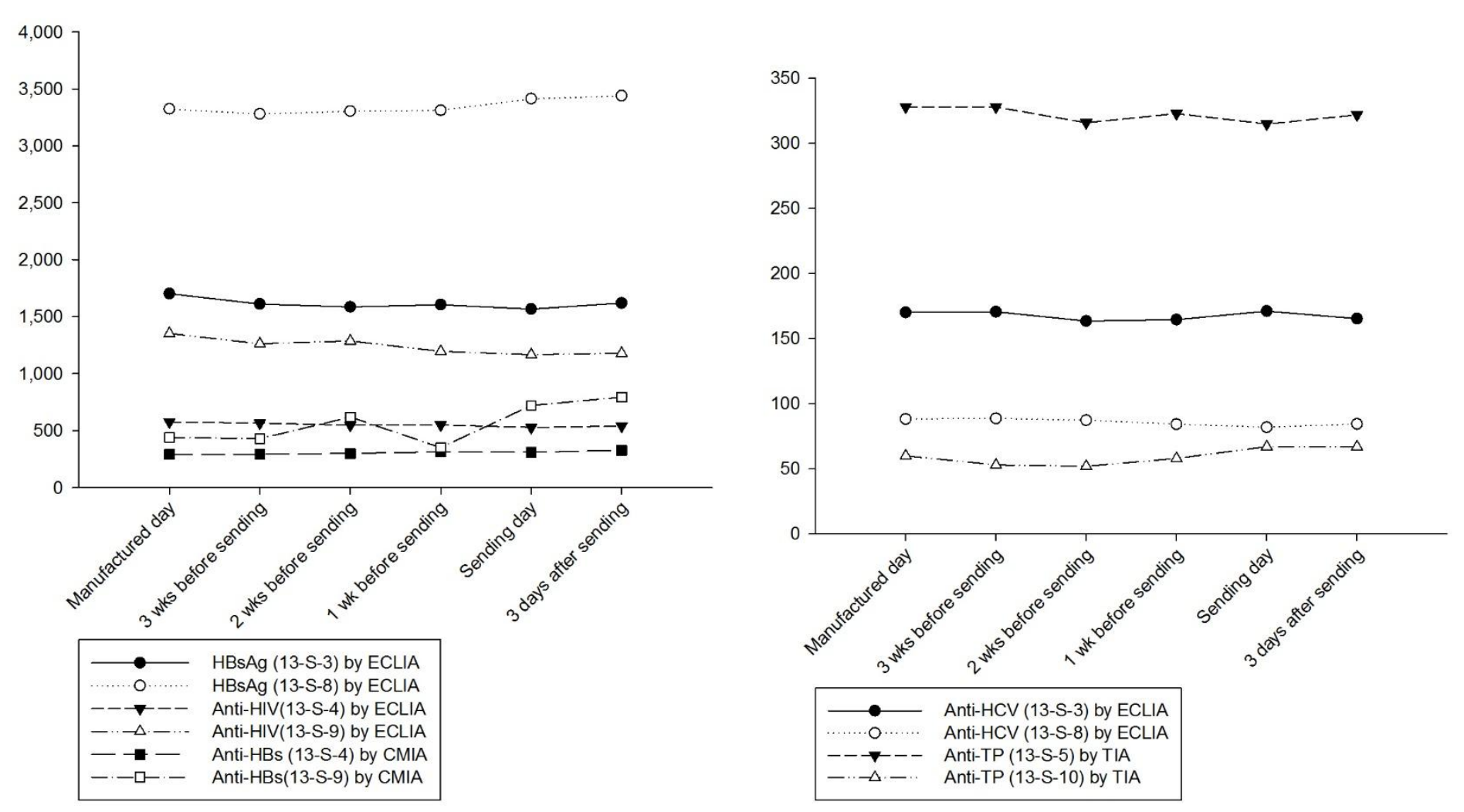

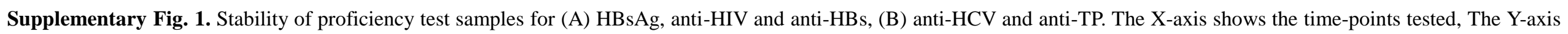

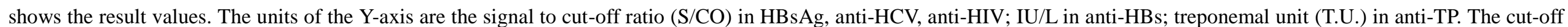

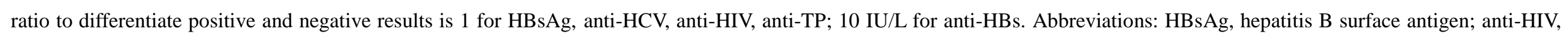

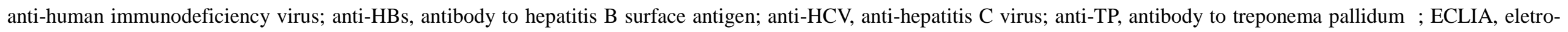
chemiluminescence immunoassay; CMIA, chemiluminescent microparticle immunoassay; TIA, turbidoimmunoassay. 